INOBIS: Jurnal Inovasi Bisnis dan Manajemen Indonesia

Volume 1, Nomor 4, September 2018

I Made Stevana Adi Santhika Sudirman; I Gusti Agung Ketut Gede Suasana

\title{
Pengaruh Kualitas Layanan Online Terhadap Kepuasan, Komitmen, dan Loyalitas Nasabah Internet Banking di Kota Denpasar
}

\author{
Oleh: \\ I Made Stevana Adi Santhika Sudirman ${ }^{1}$ \\ ${ }^{1}$ Program Studi Manajemen, Fakultas Ekonomi dan Bisnis \\ Universitas Udayana, Indonesia \\ @ mail: st3v4n4@yahoo.com \\ I Gusti Agung Ketut Gede Suasana ${ }^{2}$ \\ 2 Program Studi Manajemen, Fakultas Ekonomi dan Bisnis \\ Universitas Udayana, Indonesia \\ @mail: agung_suasana@unud.ac.id
}

\begin{abstract}
Abstrak
Pelayanan melalui internet merupakan salah satu isu, terkait dengan strategi ekspansi bisnis perbankan. Kualitas layanan secara online terbaik dapat menentukan loyalitas nasabah terhadap suatu bank. Penelitian ini dilakukan dengan tujuan untuk; menjelaskan pengaruh kualitas layanan online yang dibentuk oleh dimensi-dimensi e-service quality terhadap kepuasan nasabah; menjelaskan pengaruh kepuasan terhadap loyalitas nasabah pengguna internet banking, baik secara langsung maupun melalui mediasi komitmen nasabah. Subjek penelitian adalah nasabah bank umum di Kota Denpasar yang memanfaatkan fasilitas layanan internet banking. Anggota sampel terdiri dari para nasabah Bank Mandiri, BCA, Bank Permata, Bank CIMB Niaga, dan Bank Commonwealth di Kota Denpasar, dengan ukuran sampel sebesar 200 orang. Penentuan sampel menggunakan metode non probability sampling, yaitu purposive sampling. Data dianalisis dengan teknik analisis Structural Equation Modelling (SEM). Validitas data diuji menggunakan konfirmatori first order dan second order, sedangkan uji reliabilitas menggunakan construct reliability. Hasil analisis konfirmatori full model struktural terhadap tujuh dimensi $e$ service quality, menunjukkan bahwa kualitas informasi website, kualitas interaksi website, kualitas desain website, kehandalan, ketanggapan, jaminan dan empati, berpengaruh signifikan terhadap kepuasan nasabah. Hasil lain juga ditemukan bahwa kepuasan berpengaruh signifikan terhadap loyalitas nasabah, baik secara langsung maupun melalui mediasi secara parsial komitmen nasabah. Pengembangan layanan internet banking perlu memperhatikan dengan seksama dimensi-dimensi $e$-service quality sebagai pembentuk kualitas layanan online. Perbaikan terhadap dimensi-dimensi e-service quality diharapkan dapat meningkatkan kinerja layanan internet banking sesuai dengan harapan nasabah demi tercapainya kepuasan, komitmen, serta loyalitas nasabah.
\end{abstract}

Kata Kunci : kualitas layanan online, kepuasaan nasabah, komitmen nasabah, loyalitas nasabah, dan internet banking. 
INOBIS: Jurnal Inovasi Bisnis dan Manajemen Indonesia

Volume 1, Nomor 4, September 2018

\section{Made Stevana Adi Santhika Sudirman; I Gusti Agung Ketut Gede Suasana}

\section{Pendahuluan}

E-commerce adalah kegiatan membeli dan menjual informasi produk melalui jaringan internet. Pada umumnya, dalam penggunaan e-commerce terjadi perubahan saluran pemasaran berbasis tradisional ke arah pemasaran berbasis web, sehingga e-commerce dikenal sebagai "business to customer e-commerce". Bersamaan dengan hal tersebut, popularitas perangkat mobile di Indonesia semakin tinggi, di mana banyak pengguna internet memilih online dari ponsel atau tablet. Internet telah memberikan kontribusi yang besar bagi efektifitas dan efisiensi operasional perusahaan khususnya pada sektor perbankan. Internet World Stats (2017) menunjukkan bahwa Indonesia masuk pada rangking ke-lima dalam 20 besar negara-negara pengguna internet aktif atau terbesar (7,1 persen) di Asia (https://www.internetworldstats.com/asia.htm, 2017). Menariknya, figur ini mengalami kenaikan sebesar 15 persen dalam kurun waktu 2015-2016 (Erfiani dkk., (2016). Perbankan sebagai sebuah industri, memandang bahwa pemanfaatan teknologi memberikan efektifitas dan efisiensi dari aspek keamanan data, kecepatan pelayanan dan kemampuan bersaing. Beberapa pertimbangan industri perbankan dalam melakukan pengembangan teknologi informasi, antara lain; 1) kemudahan dan kenyamanan melakukan transaksi perbankan secara online, 2) teknologi informasi dapat mendukung layanan prima, dan mempertahankan loyalitas nasabah dalam suatu sistem hubungan (ebankingtalk.blogspot.com, 2008). Di sisi lain, nasabah mempunyai banyak persepsi dalam menentukan bank mana yang dipilih sebagai provider. Pilihan tersebut sudah tentu tertuju pada bank dengan fitur layanan dan teknologi informasi yang unggul. Persepsi nasabah terhadap jasa perbankan tidak lepas dari image yang melekat pada bank tersebut, dikaitkan dengan; jasa layanan yang disajikan, berbagai varian, dan kemampuan teknologi informasi pendukung, atau paduan dari ketiga hal tersebut. Ketersediaan delivery channel yang dapat diakses 24/7, menjadi suatu keharusan bagi bank yang ingin tetap eksis dalam merebut pasar jasa keuangan ritel dengan memanfaatkan perkembanagan teknologi informasi.

Internet banking menurut beberapa sumber media online, mengijinkan nasabah melakukan transaksi keuangan dengan jaminan keamanan website yang dioperasikan melalui bank virtual (www.en.wikipedia.org). Internet banking melibatkan nasabah dalam mengakses rekening bank dan mengambil alih transaksi perbankan. Pada level dasar, internet banking dapat diartikan sebagai pengaturan pada halaman web oleh bank untuk memberikan informasi tentang produk dan jasa, namun pada tingkat lanjutan akan melibatkan penyediaan fasilitas untuk mengakses rekening, transfer dana dan membeli produk-produk finansial atau layanan online, yang disebut sebagai transaksional online banking (Sathye, 1999). Otoritas Jasa Keuangan (OJK) mencatat, jumlah pengguna e-banking (SMS banking, phone banking, mobile banking, dan internet banking) meningkatkan sebesar 270 persen pada Tahun 2016 dan diprediksi dapat mencapai US\$130 miliar pada 2020. Jumlah ini meningkat seiring adanya perubahan perilaku dan kebutuhan masyarakat dalam memanfaatkan teknologi digital untuk melakukan aktivitas perbankan (Apriyani, 2016). Kemudahan yang ditawarkan dalam dunia digital telah mendorong meningkatnya transaksi melalui media online.

Internet banking merupakan pendukung utama dalam memperluas operasi pasar. Laporan The Jakarta Post melalui media online, pada surve yang dilakukan oleh divisi konsultan AMI (Asia Marketing Intelligence) menguraikan sekitar 81 persen nasabah perbankan online menggunakan layanan memeriksa saldo rekening, sedangkan sisanya 19 persen melakukan transfer atau membayar tagihan seperti; listrik, telepon atau kartu kredit. Faktor yang menentukan naiknya tingkat pertumbuhan penggunaan internet banking adalah peningkatan 
INOBIS: Jurnal Inovasi Bisnis dan Manajemen Indonesia

Volume 1, Nomor 4, September 2018

\section{Made Stevana Adi Santhika Sudirman; I Gusti Agung Ketut Gede Suasana}

standar hidup dan jaminan kualitas layanan online perbankan yang cepat, tepat dan aman. Bank berkepentingan memberikan pelayanan jasa dengan kualitas yang terbaik, khususnya pada layanan online. Industri perbankan harus paham dimensi yang digunakan nasabah untuk menilai kualitas layanan dan memonitor tingkat kinerja layanan yang diberikan. Beberapa studi telah membahas faktor-faktor kunci dimensi kualitas layanan di lingkungan perbankan secara tradisional. Namun, sedikit literatur yang membahas dimensi kualitas layanan internet banking di industri perbankan, dan pengaruhnya dengan kepuasan nasabah (Jun dan Cai, 2001).

Internet banking memberikan beberapa keuntungan dibandingkan resikonya, antara lain: ekspansi bisnis, loyalitas, biaya, keunggulan kompetitif, media informasi model bisnis baru, dan tuntutan kebutuhan nasabah, perubahan interaksi masyarakat menuntut perbankan melakukan perubahan. Online banking dibandingkan dengan layanan perbankan kovensional, lebih banyak melibatkan interaksi non-human dengan sistem infomasi bank online. Promosi yang cepat tanggap, pengiriman just-in-time dari layanan secara online meningkatkan share informasi antara bank dan nasabah (Lovelock dan Wirtz, 2007).

Pelaksanaan interaksi online dengan nasabah, membutuhkan website sebagai media interaksi, yang sepenuhnya dikendalikan oleh nasabah. Intensitas interaksi melalui online banking mengindikasikan tingkat loyalitas nasabah pada bank yang bersangkutan. Loyalitas dapat terbentuk dari kepuasan atas pengalaman jasa dan secara konsisten berkomitmen untuk melakukan pembelian ulang. Loyalitas menurut Oliver (1999) adalah adalah suatu keadaan di mana terdapat komitmen yang kuat dalam pembelian ulang atau penggunaan kembali barang atau jasa secara konsisten, meskipun situasi pengaruh dan usaha-usaha pemasaran berpotensi untuk menyebabkan perilaku berubah. Ketika teknologi informasi tersebut mampu mengakomodasi segala kebutuhan nasabah, maka terjalin hubungan yang erat bahkan bersifat pribadi antara industri perbankan dan nasabah (Lang dan Colgate, 2003). Taylor dan Cacanua (2002) dalam Purti dan Suasana (2017) mengemukan bahwa kepuasan pelanggan mampu memberikan pengaruh signifikan terhadap loyalitas. Pendapat tersebut didukung oleh Hallowell (1996) dalam Wendha at al (2013) mengemukakan bahwa customer satisfaction (kepuasan pelanggan) adalah prasyarat loyalitas pelanggan.

Kepuasan pelanggan adalah isu kritis dari kesuksesan sistem bisnis, tradisional maupun online. Dasar pemahaman pokok tentang faktor-faktor yang berdampak pada kepuasan pelanggan berbasis web, memiliki kepentingan yang besar dalam e-commerce. Kebutuhan akan riset pada kepuasan pelanggan berbasis web difokuskan pada tuntutan meningkatnya permintaan untuk profitabilitas jangka panjang (Balasubramanian dkk., 2003). Kepuasan pelanggan dalam konteks e-commerce, memerlukan pemahaman yang jelas. Kepuasan pelanggan, apabila dibarengi dengan komitmen hubungan yang harmonis, dapat memperkuat loyalitas. Morgan dan Hunt (1994) dalam Wendha at al., (2013) menyatakan komitmen pelanggan didefinisikan sebagai keseluruhan aktivitas pemasaran yang secara langsung mempertahankan, mengembangkan dan memelihara pertukaran hubungan secara sukses.

Kepuasan pelanggan seringkali dikaitkan dengan kualitas jasa layanan yang diterima. Kualitas layanan merupakan kunci dari ukuran kepuasan dan beberapa studi mengidentifikasi dimensi-dimensi kualitas layanan beserta indikator-indikator ukurnya. Evaluasi standar kualitas layanan dapat dilakukan dengan membandingkan antara kenyataan yang ada dengan hasil yang diharapkan. Jika pencapaian yang ditunjukkan melebihi harapannya, maka pelanggan terpuaskan (Kotler dan Keller, 2013). Standar dimensi kualitas layanan yang tradisional tidak dapat secara langsung diaplikasikan di dunia perbankan khususnya untuk layanan internet banking, karena 
INOBIS: Jurnal Inovasi Bisnis dan Manajemen Indonesia

Volume 1, Nomor 4, September 2018

\section{Made Stevana Adi Santhika Sudirman; I Gusti Agung Ketut Gede Suasana}

menunjukan perbedaan dalam proses yang unik dalam pemberian layanan. Salah satu instrumen penilaian kepuasan pelanggan adalah SERVQUAL (Service Quality), meliputi; tangible, reliability, responsiveness, assurance dan empathy (Parasuraman dkk., 1998). Adopsi kualitas layanan yang baru di dunia e-commerce adalah kualitas layanan berbasis web. Definisi kualitas layanan online adalah tingkat di mana sebuah website dapat memfasilitasi secara efisien dan efektif dalam melakukan pembelian, penjualan dan pengiriman suatu produk (Parasuraman dkk., 2005).

Pengembangan dimensi yang dilakukan dalam penelitian ini dikaitkan dengan masalah SERVQUAL, ditinjau dari konteks online. Dimensi tangible, dimodifikasi dan dikategorikan sebagai isi web (web content). Perubahan tersebut menggunakan tiga konstruk dimensi yang dikenal dengan WEBQUAL (Website Quality), terdiri dari web information quality, web interaction quality, site design quality (Barnes dan Vidgen, 2001). Konstruk yang terbentuk dari SERVQUAL digabungkan dengan WEBQUAL sehingga menjadi tujuh dimensi. Dimensi-dimensi tersebut dipergunakan untuk mengukur kualitas layanan online dan pengaruhnya terhadap kepuasan dan loyalitas nasabah pengguna internet banking di Kota Denpasar.

\subsection{Rumusan Masalah}

1) Bagaimanakah pengaruh kualitas layanan online terhadap kepuasan nasabah dalam penggunaan internet banking di Kota Denpasar?

2) Bagaimanakah pengaruh kepuasan terhadap komitmen nasabah dalam penggunaan internet banking di Kota Denpasar?

3) Bagaimanakah pengaruh kepuasan terhadap loyalitas nasabah dalam penggunaan internet banking di Kota Denpasar?

4) Bagaimanakah pengaruh komitmen terhadap loyalitas nasabah dalam penggunaan internet banking di Kota Denpasar?

\subsection{Tujuan Penelitian}

1) Menjelaskan pengaruh kualitas layanan online terhadap kepuasan nasabah pada penggunaan internet banking di Kota Denpasar.

2) Menjelaskan pengaruh kepuasan terhadap komitmen nasabah pada penggunaan internet banking di Kota Denpasar.

3) Menjelaskan pengaruh kepuasan terhadap loyalitas nasabah pada penggunaan internet banking di Kota Denpasar.

4) Menjelaskan pengaruh komitmen terhadap loyalitas nasabah pada penggunaan internet banking di Kota Denpasar.

\section{Landasan Teori, Pengembangan Hipotesis dan Konsep Penelitian}

\subsection{Kualitas Layanan Online dan Kepuasan Nasabah}

Kualitas pelayanan online menjadi sesuatu yang penting dalam penentuan kesuksesan atau kegagalan suatu bisnis. Pelayanan dalam lingkungan elektronik (e-service) merupakan model penyerahan jasa dengan menggunakan media yang relatif baru, yaitu web (Voss 2003). 
INOBIS: Jurnal Inovasi Bisnis dan Manajemen Indonesia

Volume 1, Nomor 4, September 2018

\section{Made Stevana Adi Santhika Sudirman; I Gusti Agung Ketut Gede Suasana}

Parasuraman dkk. (2005) menyatakan definisi kualitas layanan online (e-service quality) dalam interaksinya dengan website adalah kemampuan sebuah website secara efektif dan efisien memfasilitasi konsumen dalam hal berbelanja, melakukan pembelian dan proses penyerahan barang atau jasa. Penilaian kualitas website tidak hanya pada saat interaksi penyerahan jasa tetapi juga interaksi setelah mendapatkan layanan.

Skala dimensi SERVQUAL tidak dapat diterapkan secara langsung pada e-service quality, tetapi dimensi-dimensi tersebut dapat dirancang ulang untuk mendekati kriteria dari e-service quality. Meskipun demikian, tambahan dimensi diperlukan untuk melengkapi secara utuh rancangan dari e-service quality. Parasuraman dkk. (2005) telah mengembangkan dimensi dalam mengukur kualitas layanan online yang berasal dari service quality secara tradisional. Dimensi inti dari kualitas layanan online telah dikembangkan sebagai E-S-QUAL (e-core service quality), yaitu; efesiensi (efficiency), pemenuhan (fulfillment), ketersediaan sistem (system availability), dan privasi (privacy). Sedangkan ukuran kualitas layanan online sesudah proses jasa dikenal sebagai E-RecS-QUAL (e-recovery service quality), terdiri atas: ketanggapan (responsiveness), kompensasi (compensation), kontak (contact). Loiacono at al. (2002) juga merancang skala dimensi e-service quality yang dikenal sebagai $W E B Q U A L^{\mathrm{TM}}$ (website quality) terdiri dari 12 dimensi, dan dikelompokkan ke dalam empat kategori, yaitu; ease of use (ease of understanding, intuitive operation), usefulness (informational fit-to-task, tailored communication, trust, response time), entertainment (visual appeal, innovativeness, emotional appeal), complementary relationship (on-line completeness, relative advantage, consistent image).

Li dan Suomi (2009) dalam penelitiannya menyebutkan bahwa kualitas layanan online yang lengkap akan memberikan kepuasan. Swaid dan Wigand (2007) mengidentifikasi dimensi $e$ service quality dan hubungannya dengan kepuasan dan menyatakan bahwa strategi yang berhasil dalam memuaskan pelanggan adalah dengan memberikan kualitas layanan online yang superior. Wang dan Huarng (2002) meneliti faktor kunci yang mempengaruhi kepuasan pelanggan online dalam mengevaluasi berbagai toko online pada agen website. Hasilnya menunjukkan bahwa pelanggan terpuaskan apabila kualitas layanan online yang disediakan benar-benar sesuai dengan harapan pelanggan. Selain itu, Tarigan (2008), menemukan adanya tingkat asosiatif positif antara kualitas layanan online terhadap kepuasan. Hasil serupa juga ditemukan oleh; Hsu (2006), Kim at al., (2008), Lee dan Lin (2005). Berdasarkan uraian-uraian tersebut diajukan hipotesis, yaitu:

$\mathrm{H}_{1}$ : Kualitas layanan online berpengaruh positif dan signifikan terhadap kepuasan nasabah pada penggunaan internet banking di Kota Denpasar.

\subsection{Kepuasan, Komitmen dan Loyalitas Nasabah}

Kepercayaan umum bahwa kepuasan pelanggan merupakan salah satu kunci keberhasilan suatu usaha. Kepuasan merupakan faktor penting, sehingga banyak definisi yang dihasilkan untuk kepuasan pelanggan (customer satisfaction). Kotler dan Keller (2013) mendefinisikan kepuasan pelanggan adalah tingkat perasaan seseorang sebagai hasil dari perbandingan antara kenyataan dan harapan yang diterima dari sebuah produk atau jasa. Lovelock dan Wirtz (2007) menyatakan kepuasan sebagai keadaan emosional, dan reaksi pasca-pembelian yang dapat berupa kemarahan, ketidakpuasan, kejengkelan, netralitas, kegembiraan atau kesenangan. Pelanggan mengalami berbagai tingkat kepuasan atau ketidakpuasan setelah mengalami layanan sesuai dengan sejauh mana harapan terpenuhi atau terlampaui. Kepuasan pelanggan hanya dapat 
INOBIS: Jurnal Inovasi Bisnis dan Manajemen Indonesia

Volume 1, Nomor 4, September 2018

\section{Made Stevana Adi Santhika Sudirman; I Gusti Agung Ketut Gede Suasana}

tercapai dengan memberikan pelayanan yang berkualitas kepada pelanggannya. Layanan yang baik sering kali dinilai oleh pelanggan secara langsung. Oleh karena itu, diperlukan usaha untuk meningkatkan kualitas sistem pelayanan agar dapat memenuhi keinginan dan meningkatkan kepuasan pelanggan.

Kepuasan memberikan suatu dorongan kepada pelanggan untuk menjalin hubungan yang kuat dengan perusahaan. Dalam jangka panjang, ikatan ini memungkinkan perusahaan untuk memahami dengan seksama harapan pelanggan serta kebutuhannya. Jadi dengan demikian, perusahaan dapat meningkatkan kepuasan pelanggan dan pada gilirannya kepuasan tersebut dapat menciptakan kesetiaan atau loyalitas pelanggan. Hasil penelitian menunjukkan bahwa terdapat hubungan antara kepuasan dan komitmen dalam konteks online yaitu relationship commitment yang dipertimbangkan sebagai faktor kunci untuk memelihara hubungan jangka panjang (Casaló at al., (2007). Luarn dan Lin (2003) memodelkan loyalitas pelanggan dalam konteks e-service dan ditemukan bahwa komitmen merupakan konstruk yang terpisah dan memiliki pengaruh yang kuat dibandingkan konstruk lainnya. Park dan Kim (2006) juga menyatakan bahwa kepuasan dari manfaat hubungan dapat diprediksi dengan baik melalui komitmen.

Di sisi lain, Swaid dan Wigand (2009) menyatakan hubungan kepuasan dengan loyalitas dalam konteks $e$-commerce yaitu strategi taktis bagaimana melindungi loyalitas pembeli. Chung dan Shin (2008) mnemukan adanya pengaruh yang kuat dari e-satisfaction terhadap e-loyality. Luarn dan Lin (2003) juga menemukan bahwa kepuasan pelanggan, nilai yang dirasakan, dan loyalitas pelanggan masing-masing merupakan konstruk yang berbeda dan ditemukan bahwa tidak hanya kepuasan pelanggan dan nilai yang dirasakan berpengaruh langsung pada loyalitas pelanggan tetapi juga secara tidak langsung berpengaruh kepada loyalitas pelanggan melalui komitmen. Berdasarkan kajian tersebut diajukan hipotesis, yaitu:

$\mathrm{H}_{2}$ : Kepuasan berpengaruh positif dan signifikan terhadap komitmen nasabah pada penggunaan internet banking di Kota Denpasar.

$\mathrm{H}_{3}$ : Kepuasan nasabah berpengaruh positif dan signifikan terhadap loyalitas nasabah pada penggunaan internet banking di Kota Denpasar.

\subsection{Komitmen dan Loyalitas Nasabah}

Komitmen merupakan bagian penting dalam sebuah hubungan jangka panjang (Morgan dan Hunt, 1994). Komitmen adalah keinginan untuk mempertahankan keterhubungan dalam jangka panjang (Moorman dkk. dalam Morgan dan Hunt, 1994). Hubungan komitmen (relationship commitment) digambarkan sebagai konseptualisasi komitmen dalam pertukaran sosial. Sementara itu, Berry dan Parasuraman dalam Morgan dan Hunt (1994), menyatakan hubungan pelanggan dibangun atas dasar komitmen yang saling menguntungkan. Komitmen dibedakan menjadi dua jenis yaitu, calculative commitment dan affective commitment. Komitmen bersifat rentan, adalah relasi yang dijalin dengan pihak yang dapat dipercaya. Oleh sebab itu, kepercayaan adalah kontributor yang kuat bagi komitmen. Kesamaan tujuan, komunikasi dan pertukaran informasi yang terbuka dapat digunakan untuk menciptakan sikap positif dalam relasi dan dapat digunakan untuk menguatkan manfaat dari relasi.

Loyalitas pelanggan adalah suatu keadaan dimana terdapat komitmen yang kuat dalam pembelian ulang dan penggunaan kembali barang dan jasa perusahaan (Oliver, 1999). Hasil penelitian dari Park dan Kim (2006) menunjukan bahwa kepuasaan informasi dan keuntungan 
INOBIS: Jurnal Inovasi Bisnis dan Manajemen Indonesia

Volume 1, Nomor 4, September 2018

\section{Made Stevana Adi Santhika Sudirman; I Gusti Agung Ketut Gede Suasana}

sebuah hubungan berpengaruh langsung terhadap komitmen pelanggan dalam belanja online. Luarn dan Lin (2003) telah menguji hipotesis bahwa komitmen berpengaruh langsung terhadap loyalitas dalam konteks layanan online. Peneliti lain yaitu Houn at al., (2006) menemukan bahwa komitmen berpengaruh langusung terhadap loyalitas. Berdasarkan hubungan antara komitmen dengan loyalitas dalam konteks online maka dapat dibentuk hipotesis, yaitu:

$\mathrm{H}_{4}$ : $\quad$ Komitmen nasabah berpengaruh positif dan signifikan terhadap loyalitas nasabah pada penggunaan internet banking di Kota Denpasar.

\subsection{Kerangka Konsep dan Hipotesis Penelitian}

Model WEBQUAL telah dipakai para peneliti sebagai standar dalam mengukur kualitas sebuah website. Berdasarkan temuan Voss (2003) di dalam merestrukturisasi dimensi-dimensi SERVQUAL ditambah dengan restrukturisasi yang dilakukan oleh Loiacono at al., (2002) terhadap dimensi-dimensi WEBQUAL dapat diusulkan kerangka konsep penelitian berikut:

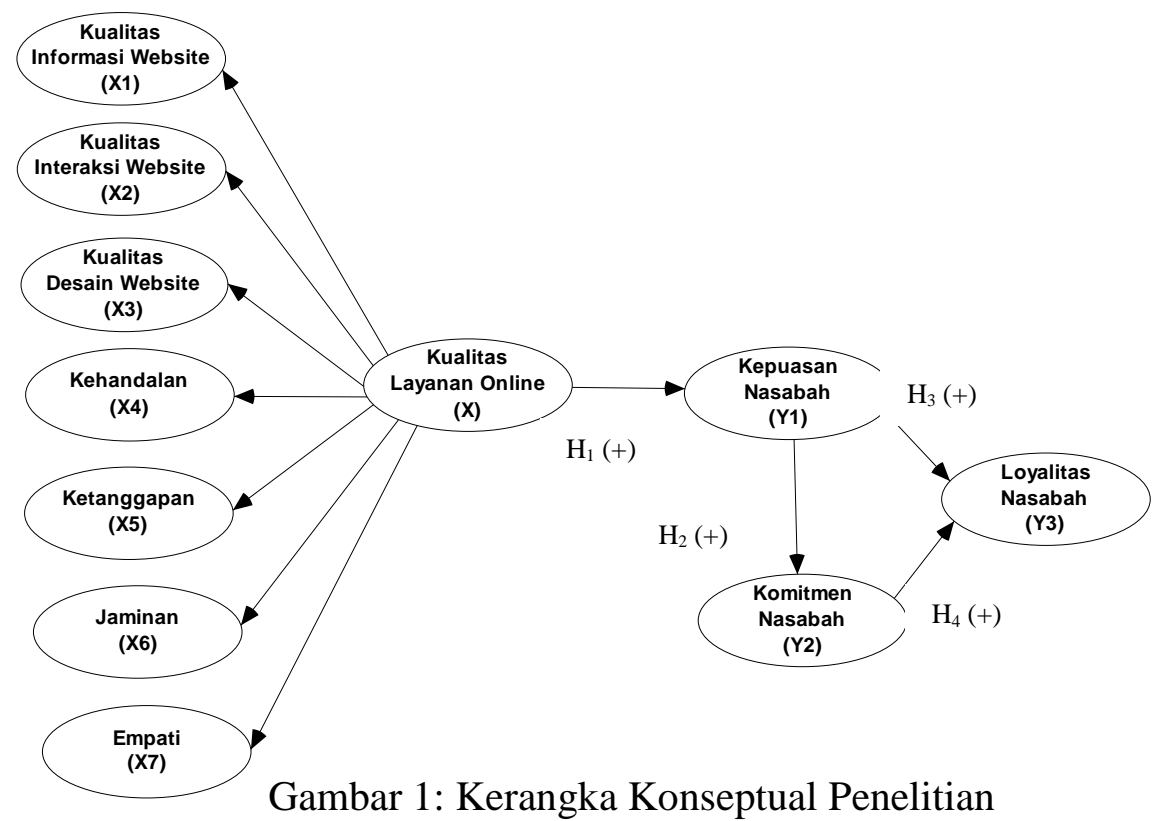

\section{Methode Penelitian}

\subsection{Populasi dan Sampel}

Populasi pada penelitian ini adalah semua nasabah yang pernah melakukan transaksi melalui internet banking pada bank-bank umum di Denpasar. Bank umum yang terdaftar di Kantor Bank Indonesia Denpasar sebanyak 43 bank umum (BI. Denpasar 2016) dan tersedia sebanyak sembilan internet banking terkenal di bank-bank umum di Indonesia (www.aturduit.com, 2017). Sampel diambil dari nasabah pada lima bank umum di Kota Denpasar yang memiliki fasilitas layanan internet banking. Kelima bank tersebut, yaitu; Bank Mandiri mewakili klasifikasi bank pemerintah, BCA, Permata, dan CIMB Niaga mewakili klasifikasi 
INOBIS: Jurnal Inovasi Bisnis dan Manajemen Indonesia

Volume 1, Nomor 4, September 2018

\section{Made Stevana Adi Santhika Sudirman; I Gusti Agung Ketut Gede Suasana}

bank swasta nasional, Bank Commonwealth mewakili klasifikasi bank asing. Menurut surve MRI (Marketing Riset Indonesia) yang diberitakan oleh bank-bank umum tersebut termasuk rangking sepuluh besar dalam transaksi perbankan melalui fasilitas $e$-banking (InfoBankNews.com, 2009).

Ukuran sampel penelitian ditentukan sebanyak 200 responden dengan 42 indikator pernyataan. Pengambilan sampel menggunakan metode sampel tidak acak (non probability sampling), melalui pendekatan purposive sampling (Sugiyono, 2004), dengan kriteria: 1. Merupakan nasabah pada salah satu dari kelima bank yang ditentukan peneliti (Bank Mandiri, BCA, Permata, CIMB Niaga, dan Commonwealth). 2. Memiliki fasilitas akses internet banking pada salah satu atau lebih dari kelima bank tersebut. 3. Telah melakukan transaksi dengan internet banking minimal dua kali dalam sebulan terakhir.

\subsection{Pengukuran dan Definisi operasional}

Pengumpulan data dilakukan dengan metode surve yaitu menggunakan kuesioner yang terbagi ke dalam 42 butir pernyataan dan dikelompokkan ke dalam; 33 (tujuh dimensi) indikator ukur kualitas layanan website, dan masing-masing tiga indikator ukur kepuasan, komitmen dan loyalitas. Penyebaran dan pengumpulan data dilakukan secara langsung kepada responden pada bank-bank sampel tersebut dengan self administered report yaitu responden diminta untuk mengisi sendiri kuesioner yang diberikan. Data yang dikumpulkan berupa data ordinal yang diukur menggunakan skala liket lima tingkat, dengan kategori dan degradasi nilai mulai dari angka 5 = Sangat Setuju, $4=$ Setuju, $3=$ Netral, $2=$ Tidak Setuju dan $1=$ Sangat Tidak setuju . Masing-masing dimensi kualitas layanan website dapat didefinisikan:

1) Web information quality (kualitas informasi website), adalah akurasi informasi website yang disajikan sesuai harapan nasabah.

2) Web interaction quality (kualitas interaksi website), adalah website yang disediakan bersifat interaktif atau mudah digunakan oleh nasabah.

3) Site design quality (kualitas desain website), adalah interface website yang divisualisasikan dalam bentuk tampilan website.

4) Reliability (kehandalan), adalah internet banking mememberikan layanan seperti yang dijanjikan kepada nasabah.

5) Responsiveness (ketanggapan), peran internet banking yang secara efektif merespon masalah nasabah.

6) Assurance (jaminan), adalah layanan internet banking menjamin keamanan dalam segala proses transaksi.

7) Empathy (empati), adalah layanan internet banking menyediakan perhatian secara individual kepada nasabah.

\subsection{Analisis Data}

Analisis data menggunakan teknik analisis SEM (Structural Equation Modelling) dengan menggunakan program SPSS. Pengujian SEM dilakukan untuk model secara keseluruhan (full model) dengan teknik konfirmatori first order dan second order serta evaluasi Goodness of Fit Indices (Santoso, 2007).

\section{Hasil dan Pembahasan}


INOBIS: Jurnal Inovasi Bisnis dan Manajemen Indonesia

Volume 1, Nomor 4, September 2018

I Made Stevana Adi Santhika Sudirman; I Gusti Agung Ketut Gede Suasana

\subsection{Hasil Uji Validitas dan Reliabilitas}

Hasil konfirmatori first order konstruk eksogen yang dimodifikasi menunjukkan bahwa semua indikator dinyatakan valid dengan $\lambda$ antara $0,512-0,866(>0,50)$ dan reliabel dengan CR antara $0,651-0,851(>0,60)$. Uji reliabilitas terhadap variabel kualitas layanan online (X) menunjukkan nilai $\mathrm{CR}>0,60$, sehingga semua dimensi e-service quality sebagai indikator pembentuk variabel kualitas layanan online $(\mathrm{X})$ dapat dikatakan valid $(\lambda=0,549-0,891)$ dan reliabel $(\mathrm{CR}=0,852)$. Ujian konfirmatori indogen antar konstruk menunjukkan bahwa semua variabel (kepuasan, komitmen dan loyalitas nasabah) menghasilkan $\lambda$ antara 0,505-0,843 (> $0,50)$ dengan tingkat signifikansi $(\mathrm{p}) \leq 0,05$, sehingga model tersebut dinyatakan valid. Uji reliabilitas konstruk (variabel kepuasan, komitmen dan loyalitas nasabah) menunjukkan nilai CR antara 0,693 - 0,842 (>0,60), sehingga konstruk endogen dapat dikatakan reliabel.

\subsection{Pengujian Hipotesis}

Pengujian hipotesis penelitian dilakukan berdasarkan hasil evaluasi full model struktural. Berdasarkan analisis SEM, taraf signifikansi estimasi parameter ditentukan dengan nilai C.R $\geq$ 1.96 dan tingkat signifikansi $(\mathrm{p}) \leq 0,05$. Hasil uji menunjukkan bahwa semua hipotesis yang diajukan, dapat dikonfirmasikan. Hipotesis 1; terdapat hubungan positif dan signifikan antara kualitas layanan online dan kepuasan nasabah pada penggunaan internet banking. Hasil uji menunjukkan hubungan signifikan dengan nilai C.R. sebesar 6,009 dan tingkat signifikansi (p) sebesar 0,000. Hipotesis 2; terdapat hubungan positif dan signifikan antara kepuasan dan komitmen nasabah pada penggunaan internet banking. Hasil uji menunjukkan bahwa hubungan tersebut signifikan dengan nilai C.R. sebesar 4,400 dan tingkat signifikansi (p) sebesar 0,000. Hipotesis 3; terdapat hubungan positif dan signifikan antara kepuasan nasabah dan loyalitas nasabah pada penggunaan internet banking. Hasil uji menunjukkan bahwa hubungan tersebut signifikan dengan nilai C.R. sebesar 2,118 dan tingkat signifikansi (p) sebesar 0,034. Hipotesis 4; terdapat hubungan positif dan signifikan antara komitmen dan loyalitas nasabah pada penggunaan internet banking. Hasil uji menunjukkan bahwa hubungan tersebut signifikan dengan nilai C.R. sebesar 3,868 dan tingkat signifikansi (p) sebesar 0,000.

Model struktural menunjukan pengaruh langsung dan tidak langsung antar variabel yang diteliti. Kualitas layanan online (X) berpengaruh langsung sebesar 0,490 terhadap kepuasan nasabah $\left(\mathrm{Y}_{1}\right)$. Kepuasan nasabah $\left(\mathrm{Y}_{1}\right)$ berpengaruh langsung sebesar 0,527 terhadap komitmen nasabah $\left(\mathrm{Y}_{2}\right)$. Kepuasan $\left(\mathrm{Y}_{1}\right)$ berpengaruh langsung terhadap loyalitas nasabah $\left(\mathrm{Y}_{3}\right)$ sebesar 0,208. Pengaruh tidak langsung antar variabel, ditemukan nilai sebesar 0,527 dari kepuasan ( $\left.\mathrm{Y}_{1}\right)$, dan 0,464 dari komitmen nasabah $\left(\mathrm{Y}_{2}\right)$ atau nilai total sebesar 0,244. Hasil tersebut diperoleh pada pengaruh tidak langsung kepuasan $\left(\mathrm{Y}_{1}\right)$ terhadap loyalitas $\left(\mathrm{Y}_{3}\right)$ melalui mediasi komitmen nasabah $\left(\mathrm{Y}_{2}\right)$.

\subsection{Pembahasan}

Kualitas layanan online terdiri atas tujuh dimensi e-service quality, membentuk satu sistem kualitas layanan online yang dilengkapi berbagai fasilitas internet banking. Koefisien standardized regression weights kualitas informasi website yang dihasilkan dari hubungan ini 
INOBIS: Jurnal Inovasi Bisnis dan Manajemen Indonesia

Volume 1, Nomor 4, September 2018

\section{Made Stevana Adi Santhika Sudirman; I Gusti Agung Ketut Gede Suasana}

adalah sebesar 0,531. Artinya bahwa dimensi kualitas informasi website memiliki nilai koefisien regresi sebesar 53,1 persen. Kualitas informasi website yang dikategorikan sebagai bagian dari kualitas isi website menawarkan informasi yang sebenar-benarnya kepada nasabah. Sehingga, informasi yang disajikan dapat memenuhi kebutuhan tentang pengetahuan informasi yang mudah dimengerti dan selalu diperbaharui, sehingga dapat meyakinkan nasabah dalam menggunakan fasilitas internet banking. Semakin akurat informasi yang ditampilkan pada website dengan tingkat kebenaran informasi yang dapat dipercaya, dan selalu up to date, serta disesuaikan dengan kebutuhan klien, maka akan mempengaruhi tingkat harapan nasabah.

Dimensi kualitas interaksi website, memiliki koefisien standardized regression weights sebesar 0,617. Artinya bahwa, kualitas kualitas interaksi website memiliki koefisien regresi sebesar 61,7 persen. Kualitas interaksi website, secara teori diperlukan dalam membentuk kualitas isi website dengan maksud adanya web yang bersifat interaktif (user friendly) ternyata memang dibutuhkan. Interaksi antara sistem dan pengguna website sangat diperhatikan pihak bank penyedia layanan online, karena tujuan pembuatan sistem adalah untuk mempermudah nasabah dalam mengelola kebutuhannya. Sistem website semaksimal mungkin dirancang untuk memenuhi kebutuhan nasabah dalam hal interaksi, misalnya; alamat website yang mudah diingat, situs yang mudah dipelajari, dan digunakan. Selain itu, efektifitas website seperti fungsi pencarian informasi dan efektifitas waktu yang diperlukan dalam memproses tiap halaman website adalah minimal harus mendapat perhatian dalam sistem yang dibentuk demi kenyamanan pengguna.

Dimensi kualitas desain website, memiliki nilai standardized regression weights sebesar 0,636, artinya bahwa kualitas desain website memiliki koefisien regresi sebesar 63,6 persen. Kualitas desain website merupakan bagian dalam usaha meningkatkan harapan nasabah. Bukti fisik seperti tampilan website yang menarik, ciri khas dan bentuk desain, pengaturan layout desain serta pengaturan komposisi antara huruf, warna gambar maupun grafik pada website akan memberikan kesan bahwa website internet banking telah dirancang dengan baik. Bank memandang bahwa segala sesuatu fasilitas yang dikeluarkan atau ditawarkan kepada nasabah hendaknya memiliki nilai positif tersendiri dan dapat memberikan kesan atau pengalaman baru bagi nasabah. Tujuannya adalah agar nasabah tertarik untuk menggunakan fasilitas tersebut. Misalnya, BCA dengan ciri khas warna biru, Bank CIMB Niaga yang berwarna dominan merah, atau Bank Commonwealth yang tampilannya berwarna kuning, dan sebagainya. Desain website dipandang sebagai sesuatu yang dapat menarik perhatian nasabah untuk dapat dengan mudah mengenal dan memberi kesan tertentu. Sehingga, penilaian nasabah terhadap interface website yang divisualisasikan dengan tampilan dan rancangan yang baik akan mempengaruhi harapan nasabah.

Dimensi kehandalan, memiliki koefisien standardized regression weights sebesar 0,902, artinya bahwa kehandalan memiliki koefisien regresi sebesar 90,2 persen. Kehandalan akan fungsi dan kegunaan internet banking seperti yang dijanjikan oleh bank penyedia jasa layanan online sangat dibutuhkan oleh nasabah. Kehandalan dimaksud meliputi real time process yaitu transaksi yang dilakukan nasabah langsung diproses pada saat itu juga. Transaksi yang diproses selanjutnya dijalankan oleh sistem dengan benar dan tepat. Artinya, meminimalisasi terjadinya kesalahan pada saat proses transaksi berlangsung, serta layanan internet banking yang selalu aktif 24/7 atau dapat dikatakan bahwa dalam kondisi apapun internet banking harus tetap tersedia untuk digunakan.

Dimensi dayatanggap, memiliki koefisien standardized regression weights sebesar 0,453, 
INOBIS: Jurnal Inovasi Bisnis dan Manajemen Indonesia

Volume 1, Nomor 4, September 2018

\section{Made Stevana Adi Santhika Sudirman; I Gusti Agung Ketut Gede Suasana}

artinya bahwa dayatanggap memiliki koefisien regresi sebesar 45,3 persen. Pengaruh yang diberikan pada dimensi ini lebih kecil dibandingkan dimensi-dimensi lainnya. Ketanggapan yang disediakan oleh fasilitas internet banking kurang memberikan kontribusi terhadap layanan secara keseluruhan. Proses layanan penanganan masalah secara langsung dari fasilitas internet banking tidak dapat dimanfaatkan secara maksimal oleh nasabah, sehingga harapan nasabah kurang terhadap hal ini. Nasabah cenderung menyelesaikan masalah yang terjadi pada saat melakukan transaksi dengan internet banking melalui customer service, dan tidak melalui petunjuk tutorial yang disediakan oleh website internet banking. Pada dasarnya setiap sistem yang telah dirancang sebelumnya pasti menyediakan aturan dan tata cara dalam menyelesaikan masalah yang terjadi pada saat melakukan proses transaksi internet banking. Ketidaktahuan nasabah tentang kemampuan sistem yang ada membuat penanganan masalah yang dihadapi nasabah tidak maksimal. Misalnya, e-mail tidak dipergunakan sebagaimana mestinya ketika terjadi masalah yang seharusnya ada balasan dari automatic reply dari system administrator untuk memandu nasabah menyelesaikan masalah yang terjadi. Jika masalah yang terjadi tidak dapat diselesaikan secara sistem, biasanya nasabah diminta untuk menghubungi layanan call centre atau IT helpdesk bank yang bersangkutan.

Dimensi jaminan memiliki koefisien standardized regression weights sebesar 0,641, artinya bahwa jaminan memiliki nilai regresi sebesar 64,1 persen. Jaminan keamanan yang baik dalam bertransaksi melalui fasilitas internet banking akan memberikan harapan yang baik pula bagi nasabah karena rasa aman yang disediakan. Jaminan kemananan dan proteksi dalam bertransaksi sudah terintegrasi penuh ke dalam sistem internet banking dan hal tersebut merupakan suatu paket fasilitas standar. Misalnya, ketika memulai suatu sistem, keamanan seperti password atau tambahan perangkat keamanan lainnya seperti token pin merupakan hal yang utama. Jaminan keamanan dan proteksi pada saat menggunakan layanan tersebut sudah merupakan satu paket yang tidak bisa dipisahkan karena prosedur jaminan bertransaksi sudah diatur dalam peraturan bank. Selain itu, nasabah meyakini jaminan rasa aman juga diberikan berdasar atas reputasi yang dimiliki oleh bank penyedia layanan internet banking.

Dimensi empati memiliki koefisien standardized regression weights sebesar 0,596, artinya bahwa empati memiliki koefisien regresi sebesar 59,6 persen. Kemampuan layanan internet banking untuk memberikan informasi tentang transaksi yang dilakukan nasabah dan dapat melacak transaksi yang telah dilakukan sebelumnya membuat dimensi empati mampu memberikan konstribusi terhadap harapan nasabah. Fasilitas yang disesuaikan dengan kebutuhan nasabah (customized) merupakan hal yang menarik bagi nasabah, seperti; cara men-transfer dana ke rekening sendiri di bank, men-transfer dana antar bank menggunakan jenis transfer SKN (Sistem Kliring Nasional) atau menggunakan jenis transfer RTGS (Real Time Gross Settlement), bahkan men-transfer dana ke luar negeri dengan menggunakan media SWIFT (Society for Worldwide Interbank Financial Telecommunication) pada layanan internet banking. Hal tersebut merupakan indikasi bahwa fasilitas internet banking mampu menyesuaikan fasilitasnya dengan kebutuhan nasabah. Tambahan terhadap fasilitas internet banking selain cara melakukan transfer juga menjadi faktor yang membuat dimensi empati dapat diterima oleh nasabah, seperti misalnya dalam hal penyediaan atau penjualan produk-produk perbankan juga menjadi salah satu hal yang baru. Menawarkan produk perbankan seperti deposito, produk reksadana tanpa melakukan interaksi langsung dengan customer service atau marketing dengan pihak bank melalui fasilitas internet banking merupakan hal yang menarik bagi nasabah. 
INOBIS: Jurnal Inovasi Bisnis dan Manajemen Indonesia

Volume 1, Nomor 4, September 2018

\section{Made Stevana Adi Santhika Sudirman; I Gusti Agung Ketut Gede Suasana}

Hasil analisis pengaruh kualitas layanan online terhadap kepuasan nasabah menunjukkan hasil positif dan signifikan pada penggunaan internet banking. Koefisien standardized regression weights yang dihasilkan sebesar 0,490 dengan tingkat signifikansi (p) sebesar 0,000. Artinya bahwa kualitas layanan online berpengaruh terhadap kepuasan nasabah sebesar 49 persen. Penelitian ini mendukung penelitian; Li dan Suomi (2009); Swaid dan Wigand (2007); Wang dan Huarng (2002); Tarigan (2008); Hsu (2006); Kim dkk. (2008) dan Lee dan Lin (2005). Hasilhasil penelitian tersebut menyatakan terdapat pengaruh positif kualitas layanan online terhadap kepuasan pelanggan. Kelengkapan kualitas layanan online yang melibatkan tujuh dimensi $e$ service quality sangat berperan dalam menyuguhkan suatu kinerja fasilitas layanan internet banking. Semakin lengkap fitur-fitur layanan internet banking maka akan meningkatkan kepuasan nasabah dalam menggunakan fasilitas tersebut.

Pengaruh kepuasan terhadap komitmen nasabah, menunjukkan hasil positif dan signifikan pada penggunaan internet banking. Koefisien standardized regression weights yang dihasilkan sebesar 0,527 dengan tingkat signifikansi (p) sebesar 0,000. Artinya bahwa kepuasan nasabah berpengaruh terhadap komitmen nasabah sebesar 52,7 persen. Penelitian ini mendukung penelitian yang dilakukan; Casaló dkk. (2007); Luarn dan Lin (2003); Park dan Kim (2006). Hasil-hasil penelitian tersebut menyatakan bahwa salah satu cara dalam memelihara hubungan jangka panjang yang sukses dengan nasabah adalah menjaga komitmen hubungan dalam konteks layanan online. Kualitas layanan online yang mendukung layanan internet banking, akan menjadikan fasilitas layanan online tersebut maksimal dan dapat dihandalkan dalam melakukan transaksi, dan pada akhirnya akan mempengaruhi komitmen nasabah secara langsung. Keberhasilan layanan internet banking dalam melakukan dan menjalankan transaksi yang dilakukan oleh nasabah, dan memberikan layanan yang sesuai dengan kebutuhan akan meningkatkan keyakinan dan kepercayaan nasabah sehingga akan meningkatkan komitmen nasabah.

Pengaruh kepuasan terhadap loyalitas nasabah adalah positif dan signifikan pada penggunaan internet banking. Koefisien standardized regression weights yang dihasilkan sebesar 0,208 dengan tingkat signifikansi (p) sebesar 0,034. Artinya bahwa kepuasan nasabah berpengaruh terhadap loyalitas nasabah sebesar 20,8 persen. Penelitian ini mendukung penelitian yang dilakukan oleh; Swaid dan Wigand (2009); Chung dan Shin (2008); Luarn dan Lin (2003). Hasil penelitian tersebut menggambarkan bahwa secara potensial kepuasan pelanggan akan berpengaruh terhadap loyalitas pelanggan. Keyakinan nasabah yang tinggi diimbangi dengan penyediaan layanan internet banking yang semakin baik, akan meningkatkan loyalitas nasabah terhadap layanan tersebut. Tingkat loyalitas nasabah dapat dinilai dari beberapa kondisi misalnya, nasabah dapat merekomendasikan layanan internet banking kepada orang lain atau koleganya karena kinerja fasilitas internet banking telah sesuai atau dapat melebihi yang diharapkan. Akibatnya, persepsi atas layanan internet banking akan menjadi lebih positif dan dapat menjadi pilihan dan alternatif utama dalam melakukan transaksi perbankan selanjutnya di masa yang akan datang.

Pengaruh komitmen terhadap loyalitas nasabah adalah positif dan signifikan terhadap loyalitas nasabah pada penggunaan internet banking. Nilai standardized regression weights yang dihasilkan dari hubungan ini sebesar 0,464 dengan tingkat signifikansi (p) sebesar 0,000. Artinya bahwa komitmen nasabah berpengaruh terhadap loyalitas nasabah sebesar 46,4 persen. Penelitian ini mendukung penelitian yang dilakukan oleh; Park dan Kim (2006); Luarn dan Lin (2003); Houn dkk. (2006). Penelitian tersebut menyatakan bahwa komitmen merupakan variabel kritis 
INOBIS: Jurnal Inovasi Bisnis dan Manajemen Indonesia

Volume 1, Nomor 4, September 2018

\section{Made Stevana Adi Santhika Sudirman; I Gusti Agung Ketut Gede Suasana}

yang akan mempengaruhi loyalitas pelanggan. Komitmen yang dibangun haruslah memiliki hubungan yang kuat dan tetap terjaga, sehingga dengan meningkatnya keyakinan nasabah terhadap bank penyedia layanan online beserta fasilitas internet banking-nya, akan menyebabkan terjaganya loyalitas nasabah. Hasil dari pengaruh komitmen terhadap layanan internet banking adalah janji untuk mempergunakan layanan tersebut secara terus-menerus dan keinginan untuk tidak berpindah dari bank penyedia layanan internet banking. Dilain pihak, komitmen untuk membayar biaya yang dikenakan juga menjadi komitmen bagi nasabah untuk tidak berpindah menggunakan layanan internet banking pada bank lain. Nasabah cenderung lebih memilih bank penyedia layanan internet banking yang mengenakan biaya atas transaksi yang dilakukan nasabah lebih rendah atau bahkan free fee. Semakin tinggi komitmen dalam penggunaan layanan internet banking maka semakin loyal nasabah untuk terus menggunakan layanan internet banking.

\section{Simpulan}

Berdasarkan hasil-hasil pembahasan sebelumnya ditemukan bahwa: Kualitas layanan online yang dibentuk oleh tujuh dimensi e-service quality berpengaruh signifikan terhadap kepuasan nasabah dalam penggunaan internet banking di Kota Denpasar. Semakin berkualitas layanan online internet banking, maka semakin puas nasabah terhadap pelayanan bank tersebut. Kepuasan berpengaruh signifikan terhadap komitmen nasabah dalam penggunaan internet banking di Kota Denpasar. Artinya, semakin meningkat kepuasan nasabah maka komitmennya semakin tinggi dalam menggunakan internet banking. Kepuasan nasabah berpengaruh signifikan terhadap loyalitas penggunaan internet banking di Kota Denpasar. Berarti bahwa semakin meningkat kepuasan nasabah, maka semakin loyal nasabah untuk menggunakan internet banking dalam bertransaksi. Komitmen berpengaruh positif dan signifikan terhadap loyalitas nasabah dalam penggunaan internet banking di Kota Denpasar. Semakin tinggi komitmen akan semakin loyal nasabah dalam penggunaan internet banking. Penciptaan kualitas layanan online yang memadai pada fasilitas internet banking, merupakan solusi yang baik bagi bank untuk memperkuat kontribusi internet banking pada loyalitas transaksi perbankan. Segala kelebihan fasilitas internet banking yang dibangun dengan investasi yang besar sudah pasti mengandung risiko. Namun, internet banking mampu menciptakan tantangan tersendiri bagi pengendalian loyalitas nasabah. Jadi, diperlukan adanya edukasi kepada kayyawan dan nasabah mengenai penggunaan dan pelayanan fasilitas internet banking yang benar dan aman.

\section{Daftar Pustaka}

Anderson, R.E. dan Srinivasan, S.S., 2003. E-Satisfaction and E-Loyalty: A Contingency Framework. Journal of Psychology \& Marketing, Vol. 20(2): pp.123-138.

Apriyani, 2016. 2020, Potensi e-commerce di Indonesia Mencapai US\$130 Miliar, http://infobanknews.com/tag/e-banking, diakses 7 Maret 2017

Arunachalam, L. dan Sivasubramanian, M. 2007. Theoritical Framework To Measure The User Satisfaction In Internet banking, Academic Open Internet Journal, ISSN 1311-4360, Volume 20, 2007, www.acadjournal.com.

Asubonteng, P., McCleary, K. J., dan Swan, J. E. 1996. SERVQUAL Revisited: A Critical Review of Service Quality, The Journal of Services Marketing, Santa Barbara: 1996. Vol. 10, Iss. 6; pg. 62. 
INOBIS: Jurnal Inovasi Bisnis dan Manajemen Indonesia

Volume 1, Nomor 4, September 2018

\section{Made Stevana Adi Santhika Sudirman; I Gusti Agung Ketut Gede Suasana}

Balasubramanian, S., Konana, P., dan Menon, N. M., 2003. Customer Satisfaction in Virtual Environments: A Study of Online Investing, Journal of Management Science, 49, 7: pp871-889.

Barnes, S. dan Vidgen, R., 2001. Assessing The Quality of Auction Web Sites, Proceedings of the Hawaii International Conference on Systems Sciences, Hawaii, January 3-6: pp1-26

Casaló, L. V., Flavián, C. dan Guinalíu, M., 2007. Successful Relationship in The E-Banking Business. Online Information Review Journal. 31,5: pp583-603.

Chung, K.H. dan Shin, J.I., 2008. The Relationship among e-Retailing Attributes, e-Satisfaction and e-Loyalty. Management Review: An International Journal. Volume 3 Number 1: pp. $23-45$

Erfiani, Sahara, dan Heriyanto, 2016. Data Statistik Direktorat Jendral Sumber Daya dan Perangkat Pos dan Informatika Kementrian Komunikasi dan lnformatika Rl, Semester 2, Kementerian Komunikasi dan Informatika, Direktorat Jenderal Sumber Daya dan Perangkat Pos dan Informatika, Jakarta

Ghozali, I., 2008. Model Persamaan Struktural Konsep dan Aplikasi dengan Program Amos 16.0. Badan penerbit Universitas Diponegoro Semarang, 2008.

Houn, G.C., Edward, T. C. dan Ayi, Y., 2006. The Effects of Relationship Commitment and Trust on Business to Consumer Electronic Commerce - The Case of Taiwan. The Business Review Journal, Communications of the International Information Management Association, Volume 3 Issue 1: pp.35-45

Hsu, H., 2006. An Empirical Study of Web Site Quality, Customer Value, and Customer Satisfaction Based on E-Shop. The Business Review Journal, Cambridge, 5, 1: p.190.

Jun, M. dan Cai, S. 2001. The Key Determinants of Internet Banking Service Quality: A Content Cnalysis, The International Journal of Bank Marketing, Vol. 19, Issu 7: pp276-291.

Kim, J., Jin, B. dan Swinney, J. L., 2008. The role of etail quality, e-satisfaction and e-trust in online loyalty development process. Journal of Retailing and Consumer Services, doi:10.1016/j.jretconser.2008.11.019.

Kotler, P. dan Keller, K. L., 2013. Manajemen Pemasaran, Edisi Kedua Belas Jilid 1-2. Edisi Bahasa Inggris. Pearson Education, Inc. Upper Saddle River, New Jersey, PT INDEKS.

Lang, B. dan Colgate, M., 2003. Relationship Quality, On-Line Banking and The Information Technology Gap, The International Journal of Bank Marketing. 21, 1: pp29-37.

Lee, G. G. dan Lin, H. -F. 2005. Customer Perceptions of E-Service Quality in Online Shopping. International Journal of Retail \& Distribution Management, 2005; 33, 2/3; ABI/INFORM Research pg. 161.

Li, H. dan Suomi, R. 2009. A Proposed Scale for Measuring E-Service Quality. International Journal of u- and e-Service, Science and Technology, Vol. 2, No. 1: pp.1-10

Lovelock, C.H. dan Wirtz, J., 2007. Service Marketing: People, Technology, Strategy, Sixth Edition, Pearson Prentice Hall, Pearson Education International, USA.

Lovelock, C.H. dan Wright, L.K. 2007. Manajemen Pemasaran Jasa, Edisi Bahasa Indonesia, PT. INDEKS, Indonesia.

Loiacono, E.T., Chen, D. Q. dan Goodhue, D. L. 2002. Webqual ${ }^{T M}$ Revisited: Predicting The Intent To Reuse a Website. Proceeding, Eighth Americas Conference on Information Systems, pp.301-309

Loiacono, E.T., Watson, R. T. dan Goodhue, D. L., 2002. Webqual ${ }^{T M}$ : A Measure of Website Quality, American Marketing Association Conference, Austin, TX. 
INOBIS: Jurnal Inovasi Bisnis dan Manajemen Indonesia

Volume 1, Nomor 4, September 2018

\section{Made Stevana Adi Santhika Sudirman; I Gusti Agung Ketut Gede Suasana}

Luarn, P. dan Lin, H., 2003. A Customer Loyalty Model for E-Service Context, Journal of Electronic Commerce Research, VOL. 4, NO. 4: pp.156-167

Mukherjee, A. dan Nath, P., 2003. A Model of Trust in Online Relationship Banking, The International Journal of Bank Marketing. Vol. 21, Issu 1: p.5

Morgan, R. M. dan Hunt, S. D., 1994. The Commitment-Trust Theory of Relationship Marketing, Journal of Marketing, Vol. 58: pp. 20-38.

Oliver, R. L., 1999. Whence consumer loyalty. Journal of Marketing. Vol. 63: p.33-44.

Parasuraman, A. Berry, L. L. dan Zeithaml, V. A., 1985. A Conceptual Model of Service Quality and Its Implications for Future Research, Journal of Marketing (pre-1986), 49, 4: pp4150 .

1988. SERVQUAL: A Multiple-Item Scale for Measuring Service Quality, Journal of Retailing, 64 (1), 12-40.

1998. Perceived Service Quality as a Customer-Based Performance Measure: An Empirical Examination of Organizational Barriers Using An Extended Service Quality Model, Journal of Human Resource Management (1986-1998), 30, 3:pp335-364.

Parasuraman, A., Zeithaml, V. A. dan Malhotra, A., 2005. E-S-Qual: A Multiple-Item Scale for Assessing Electronic Service Quality. Journal of Service Research, V01. 7, No. 10: pp121.

Putri, D.A.M.M.D.G dan Suasana, I.G.A.K.G., 2017. Peran Kepuasan dalam Memediasi Pengaruh Kualitas Layanan terhadap Loyalitas Nasabah. E-Jurnal Manajemen Unud, Vol. 6, No. 11: h.6271-6297

Park, C. H. dan Kim, Y. G., 2006. The Effect of Information Satisfaction and Relational Benefit on Consumers' Online Shopping Site Commitments. Journal of Electronic Commerce in Organizations, 4, 1: pp. 70-90.

Rahardjo, B., 1999. Mengimplementasikan Electronic Commerce di Indonesia, PPAU Mikroelektronika - ITB, TR-PPAUME-1999-02.

Saha, P. dan Zhao, Y., 2005. Relationship Between Online Service Quality and Customer Satisfaction (A Study in Internet Banking), Master's Thesis, Luleå University of Technology, MSc Programme in Electronic Commerce, Department of Business Administration and Social Sciences Division of Industrial marketing and e-commerce: 05/083.

Santoso, S., 2001. Riset Pemasaran: Konsep dan Aplikasi dengan SPSS, PT. Elex Media Komputindo, Jakarta.

2007. Structural Equation Modelling: Konsep dan Aplikasi dengan AMOS, PT. Elex Media Komputindo, Jakarta.

Sathye, M. 1999. Adoption of Internet banking by Australian Consumers: An Empirical Investigation, The International Journal of Bank Marketing, Bradford: 1999. Vol. 17, Iss. 7; pg. 324.

Sugiyono. 2004. Metode Penelitian Bisnis, CV. Alfabeta, Jakarta.

Swaid, S.I. dan Wigand, R. T., 2007. Key Dimensions of E-commerce Service Quality and Its Relationships to Satisfaction and Loyalty. In $20^{\text {th }}$ Bled eConference eMergence: Merging and Emerging Technologies, Processes, and Institutions, Bled, Slovenia: pp.414-428.

, 2009. Measuring The Quality of E-Service: Scale Development and Initial Validation, Journal of Electronic Commerce Research, VOL 10, NO 1. 
INOBIS: Jurnal Inovasi Bisnis dan Manajemen Indonesia Volume 1, Nomor 4, September 2018

\section{Made Stevana Adi Santhika Sudirman; I Gusti Agung Ketut Gede Suasana}

Tarigan, J., 2008. User Satisfaction Using Webqual Instrument: A Research on Stock Exchange of Thailand. Jurnal Akuntansi dan Keuangan, Vol. 10, NO. 1, Mei 2008: 34-47.

The Jakarta Post, 2002. Rise in Internet Banking Transactions. www.thejakartapost.com/news/...., diakses Januari 2017.

Tjiptono, F. dan Chandra, G. (2007). Service Quality \& Satifaction, Penerbit CV. ANDI OFFSET, Yogyakarta.

Tjokro, A., 2008. Tuntutan Nasabah dan Dukungan Teknologi Informasi - Meneropong Kondisi Perbankan Indonesia Masa Depan. Available at: http://ebankingtalk.com/talks/tuntutannasabah-dan-dukungan-teknologi-informasi\#more-8. Accessed: May $26^{\text {th }} 2009$.

Voss, C. A., 2003. Rethinking Paradigms of Service: Service in a Virtual Environment. International Journal of Operations \& Production Management. 23, 1: p.88-104

Wang, M. dan Huarng, A.S., 2002. An Empirical Study of Internet Store Customer PostShopping Satisfaction. Special Issues journal of Information Systems, IACIS 3: pp.632638.

Waryanto, B. dan Millafati, Y. A., 2006. Transformasi Data Skala Ordinal ke Interval dengan menggunakan Makro Minitab, Jurnal Informatika pertanian, Vol 15, 2006.

Wendha, A.A.A.A.P., Rahyuda, I.K. dan Suasana, I.G.A.K.G., 2013. Pengaruh Kualitas Layanan Terhadap Kepuasan dan Loyalitas Pelanggan Garuda Indonesia di Denpasar. Jurnal Manajemen, Strategi Bisnis, dan Kewirausahaan, Volume 7 Nomor 1: h.19-28

Wibow o, A., 2003. Materi Pelatihan: Structural Equation Modeling, Universitas Airlangga, Surabaya.

Zeithaml, V. A., Parasuraman, A., dan Malhotra, A., 2002. Service Quality Delivery Through Web Sites A Critical Review of Extant Knowledge. Journal of the Academy of Marketing Science, Volume 30, No. 4: pp.362-375.

............., 2017. Asia Marketing Research, Internet Usage, Population Statistics and Facebook Subscribers, Internet World Stats: Usage and Populations Statistics, https://www.internetworldstats.com/asia.htm, diakses 7 Maret 2017

............., 2006. Kinerja E-Banking Yang Cangih Malah Tersingkir. Available at: http://www.infobanknews.com/artikel/artikel_cetak.php?aid=2743. Accessed: Februari 2017.

Kajian Ekonomi dan Keuangan Regional Provinsi Bali. Divisi Advisory dan Pengembangan Ekonomi, Kantor Perwakilan Bank Indonesia Provinsi Bali, Agustus 2016.

http://ebankingtalk.blogspot.com/2008/02/tuntutan nasabah dan dukungan teknologi.html, diakses 7 Maret 2017

, 2017. Panduan Ekslusif: Panduan Komprehensif untuk Produk, Layanan, dan

Perbankan di Indonesia; Jasa-Jasa dan Layanan Bank - Internet Banking, Mobile Banking, SMS

Banking. $\quad$ https://www.aturduit.com/articles/...perbankan/jasa-dan-layanan-ba..., diakses Nopember 2017. 